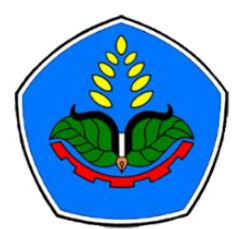

AGROPROSS

National Conference

Proceedings of Agriculture

\section{Proceedings:}

Peningkatan Produktivitas Pertanian Era Society 5.0 Pasca Pandemi

Tempat : Politeknik Negeri Jember

Tanggal : 22 Juli 2021

\section{Publisher :}

Agropross, National Conference Proceedings of Agriculture

ISBN : 978-623-94036-6-9

DOI : 10.25047 /agropross.2021.230

\title{
Serangan Hama Utama Pada Tanaman Bawang Merah Yang Diaplikasi Dengan Biostimulan
}

\author{
Author(s): Rini Murtiningsih ${ }^{(1)^{*}}$, Chotimatul Azmi ${ }^{(1)}$, Novi Irawati(1), Dwi Ningsih \\ Susilowati $^{(2)}$ \\ (1) Balai Penelitian Tanaman Sayuran, Lembang-Bandung Barat \\ (2) Balai Besar Litbang Bioteknologi dan Sumber Daya Genetik Pertanian \\ * Corresponding author: rini.murtiningsih.rm@gmail.com
}

\section{ABSTRACT}

The growth of shallots is affected by its nutritional adequacy. The provision of bio-stimulants made from selected seaweed extracts and selected endophytic bacteria is expected to increase plant growth and shallot production. In addition, the effect of bio-stimulants on the main shallot pest attack (Spodoptera exigua) also need to be known. The aim of the research that was conducted in Cikole, Lembang, West Bandung from April to May 2021 was to determine the development of S. exigua in shallot crops that received the application of various doses of 2 types of bio-stimulants. The results showed that the level of attack of S. exigua on shallots was not affected by the bio-stimulant applied in this study.

\section{Keywords:}

Shallot;

bio-

stimulants;

pest

\section{Kata Kunci: ABSTRAK}

bawang merah; biostimulan; Pertumbuhan bawang merah dipengaruhi oleh kecukupan nutrisinya. Pemberian biostimulan yang terbuat dari ekstrak rumput laut dan bakteri endofit terpilih diharapkan dapat meningkatkan pertumbuhan tanaman dan produksi bawang merah. Selain itu, pengaruh pemberian biostimulan terhadap serangan organisme hama. pengganggu tanaman utama bawang merah (Spodoptera exigua) juga perlu diketahui. Penelitian yang dilaksanakan di Desa Cikole, Lembang, Bandung Barat pada bulan April-Mei tahun 2021 dilakukan untuk mengetahui perkembangan $S$. exigua di pertanaman bawang merah yang mendapatkan aplikasi 2 jenis biostimulan tanaman bawang merah dengan dosis yang berbeda. Hasil pengamatan menunjukkan bahwa tingkat serangan $S$. exigua pada tanaman bawang merah tidak dipengaruhi oleh biostimulan yang diaplikasikan dalam penelitian ini. 


\section{PENDAHULUAN}

Bawang merah (Allium ascalonicum L) merupakan komoditas sayuran yang masuk dalam family Liliaceae. Bawang merah dapat dimanfaatkan baik sebagai sayuran rempah, maupun sebagai obat tradisional karena kandungan antibiotik berupa asam amino Alliin yang dimilikinya (Marliah et al. 2012). Sejalan dengan terus meningkatnya jumlah penduduk Indonesia yang saat ini mencapai 265 juta dengan laju pertumbuhan $1,49 \%$ per tahun, permintaan bawang merah juga semakin meningkat.

Produksi bawang merah menunjukkan perkembangan setiap tahunnya terhadap permintaan bawang merah. Produksi bawang merah di Indonesia pada tahun 2018 yaitu 1.503 .438 ton, mengalami peningkatan pada tahun 2019 yaitu 1.580.247 ton, dan pada tahun 2020 mencapai 1.815.445 ton/ha (Badan Pusat Statistik, 2021). Namun demikian peningkatan yang produksi bawang merah lebih signifikan terus diperlukan untuk memenuhi kebutuhan yang terus meningkat setiap tahunnya.

Salah satu upaya untuk meningkatkan produktivitas tanaman bawang merah adalah dengan penambahan biostimulan. Biostimulan merupakan senyawa organik alami atau sintesis bukan pupuk yang berfungsi untuk meningkatkan pertumbuhan dan respon tanaman terhadap cekaman lingkungan (Du Jardin, 2012). Aplikasi biostimulan dapat memacu dan memodifikasi berbagai proses fisiologi tumbuhan, termasuk di dalamnya respirasi, fotosintesis, sintesis asam nukleat, atau penyerapan ion (Abbas, 2013). Terdapat biostimulan bersumber dari inokulan mikroba, asam humat, asam fulvat, asam amino, ekstrak rumput laut, dan ektsrak tumbuhan yang sudah dikembangkan dalam bidang pertanian (Calvo et al. (2014). Biostimulan yang bersumber dari ekstrak rumput laut umumnya mengandung unsur hara, asam amino, sitokinin, auksin, laminaran, fukoidan, alginate, dan betain yang memacu metabolisme tanaman sehingga dapat meningkatkan pertumbuhan dan hasil tanaman (Khan et al. 2009). Kandungan unsur hara dalam ekstrak rumput dapat berfungsi seperti pupuk yang berguna dalam perkecambahan, pembentukan tanaman baru, dan perkembangan tanaman yang lebih baik (Craige, 2012). Penelitian menunjukkan bahwa aplikasi biostimulan dari rumput laut dapat meningkatkan pertumbuhan dan produktivitas tanaman, seperti misalnya berat trubus dan berat akar tanaman jagung (Matysiak et al., 2011) berat umbi atau rumpun dan produksi bawang merah (Azri, 2017), pertumbuhan tanaman buncis (Vijayanandh et al., 2013), dan pertumbuhan tanaman gandum (Kumar dan Sahoo, 2011)

Penambahan mikroba endofit berupa cendawan atau bakteri juga dapat dilakukan untuk memperbaiki pertumbuhan tanaman. Mikroba endofit merupakan mikroba yang hidup di dalam jaringan tanaman, bersimbiosis mutualisme dengan tanaman inangnya, mendapatkan nutrisi dari hasil metabolisme tanaman dan kemudian membantu tanaman untuk melawan herbivora, serangga, atau patogen (Handayani, 2016). Selain itu, mikroba endofit dapat memacu pertumbuhan tanaman melalui fitohormon berupa IAA, GA3, atau sitokinin yang dihasilkannya. Penelitian menunjukkan bahwa pemberian bakteri endofit dapat meningkatkan pertumbuhan, produksi herba segar dan kering tanaman, serta produksi andrografolid pada tanaman sambiloto (Gusmaini et al., 2013).

Penelitian pendahuluan di rumah kaca menunjukkan aplikasi biostimulan dapat meningkatkan performa tanaman bawang merah. Penelitian ini dilakukan untuk mempelajari lebih lanjut pengaruh biostimulan ekstrak rumput laut yang diperkaya dengan bakteri endofit untuk meningkatkan ketahanan tanaman bawang 
merah terhadap serangan hama utama.

\section{METODOLOGI}

Penelitian ini merupakan bagian dari kegiatan pengujian formula biostimulan dengan perlakuan efisiensi pupuk kimia. Tujuan utama dari penelitian tersebut adalah untuk mengetahui apakah aplikasi biostimulan dapat meningkatkan efisiensi pemupukan pada tanaman bawang merah. Sedangkan penelitian ini dilakukan untuk mengetahui pengaruh biostimulan ekstrak rumput laut yang diperkaya dengan bakteri endofit untuk meningkatkan ketahanan tanaman bawang merah terhadap serangan hama utama.

Pengujian dilaksanakan di IP2TP Margahayu, Lembang, Jawa Barat mulai bulan April sampai Juni 2021. Bawang merah varietas Trisula ditanam menggunakan rancangan acak kelompok untuk masing-masing pengujian biostimulan. Dalam pengujian ini terdapat dua formulasi biostimulan yang diuji, yaitu Biostimulan A dan Biostimulan B. Biostimulan yang digunakan berasal dari ekstrak rumput laut, bakteri endofit asal bawang merah dan Saccharomyces cerevisiae terseleksi yang merupakan koleksi Biogen Culture Collection (Biogen $\mathrm{CC})$. Komposisi biostimulan dalam proses pengajuan paten sehingga tidak dapat ditampilkan tulisan ini.

Pengaruh masing-masing formulasi biostimulan diuji pada tanaman bawang merah yang ditanam menggunakan rancangan petak terpisah Rancangan acak kelompok dengan 9 perlakuan dan 3 ulangan. Perlakuan untuk biostimulan A meliputi (A1) Kontrol lengkap, (B1) NPK $100 \%$ ，(C1) NPK 75\% + $10 \mathrm{~mL}$ Biostimulan A (satu kali aplikasi), (D1) NPK 75\% + 5 mL Biostimulan A (tiga kali aplikasi), (E1) NPK 75\% + 5 mL
Biostimulan A (dua kali aplikasi), (F1) NPK 75\% + 3 mL Biostimulan A (tiga kali aplikasi) dan (G1) NPK $75 \%+3 \mathrm{~mL}$ Biostimulan A (dua kali aplikasi). Sedangkan untuk plot biostimulan B meliputi (A2) Kontrol lengkap, (B2) NPK $100 \%$, (C2) NPK $75 \%+10 \mathrm{~mL}$ Biostimulan B (satu kali aplikasi), (D2) NPK 75\% + 5 mL Biostimulan B (tiga kali aplikasi), (E2) NPK 75\% + $5 \mathrm{~mL}$ Biostimulan B (dua kali aplikasi), (F2) NPK 75\% + 3 mL Biostimulan B (tiga kali aplikasi) dan (G2) NPK $75 \%+3 \mathrm{~mL}$ Biostimulan B (dua kali aplikasi). Aplikasi formula biostimulan ini dilakukan menggunakan teknik aplikasi, dosis, dan frekuensi terbaik hasil penelitian tahun 2018. Sebanyak 10 tanaman sampel pada masing-masing ulangan perlakuan diamati dalam pengujian ini. Pengamatan dilakukan terhadap populasi hama utama tanaman bawang yaitu persentase serangan Spodoptera exigua, jumlah kelompok telur S. exigua, persentase serangan Liriomyza sp., dan persentase serangan Thrips sp. pengamatan dilakukan pada 25 HST hingga 46 HST. Rerata hasil pengamatan ditampilkan secara deskriptif dalam bentuk diagram beserta dengan standar eror masing-masing.

\section{HASIL DAN PEMBAHASAN}

Tujuan dari penelitian ini adalah untuk mengetahui pengaruh biostimulan berbahan dasar ekstrak rumput laut yang diperkaya dengan bakteri endofit terhadap serangan hama utama pada tanaman bawang merah. Sejauh ini terdapat sejumlah penelitian yang mempelajari pengaruh biostimulan berbahan ekstrak rumput laut untuk meningkatkan pertumbuhan tanaman, namun sedikit yang mengulas tentang pengaruhnya terhadap serangan hama pada tanaman. 


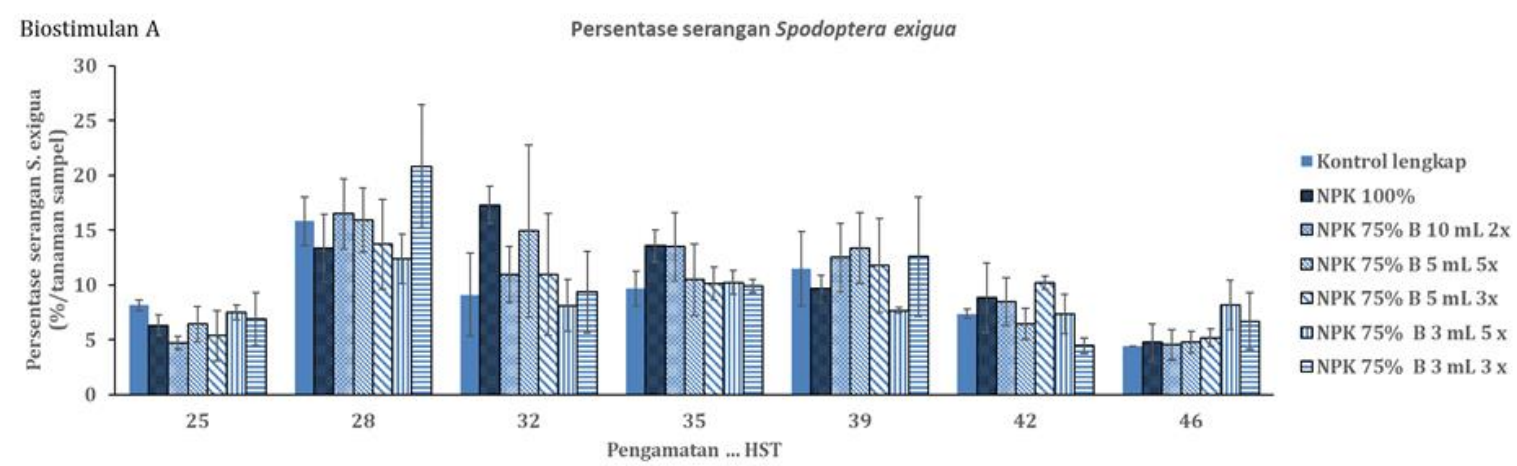

Gambar 1. Persentase serangan S. exigua pada tanaman bawang merah yang diaplikasi dengan Biostimulan A

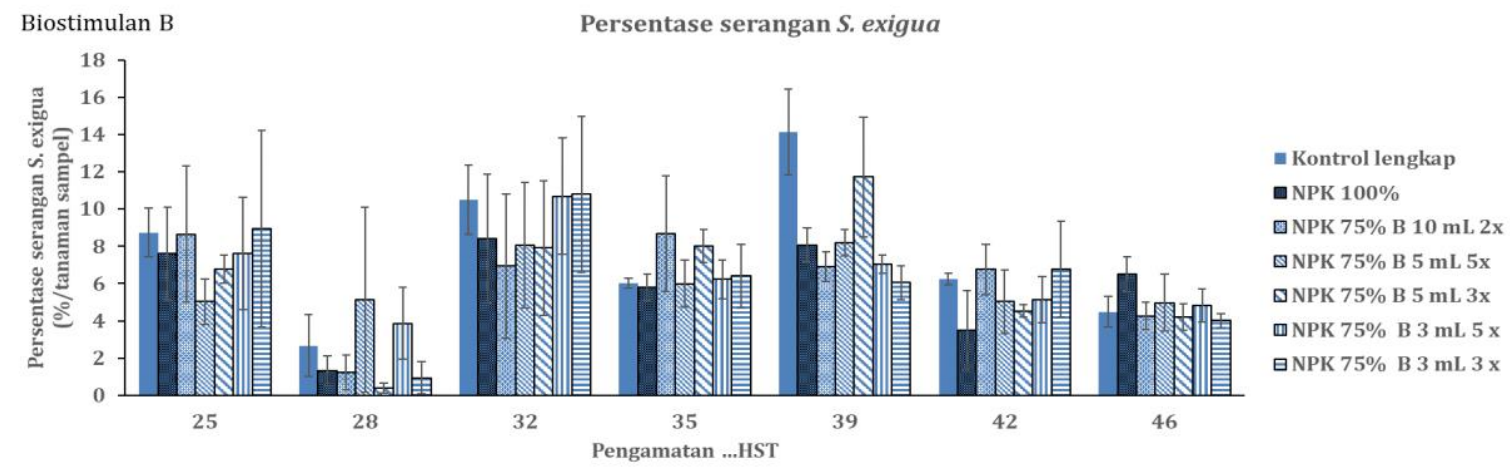

Gambar 2. Persentase serangan S. exigua pada tanaman bawang merah yang diaplikasi dengan Biostimulan B

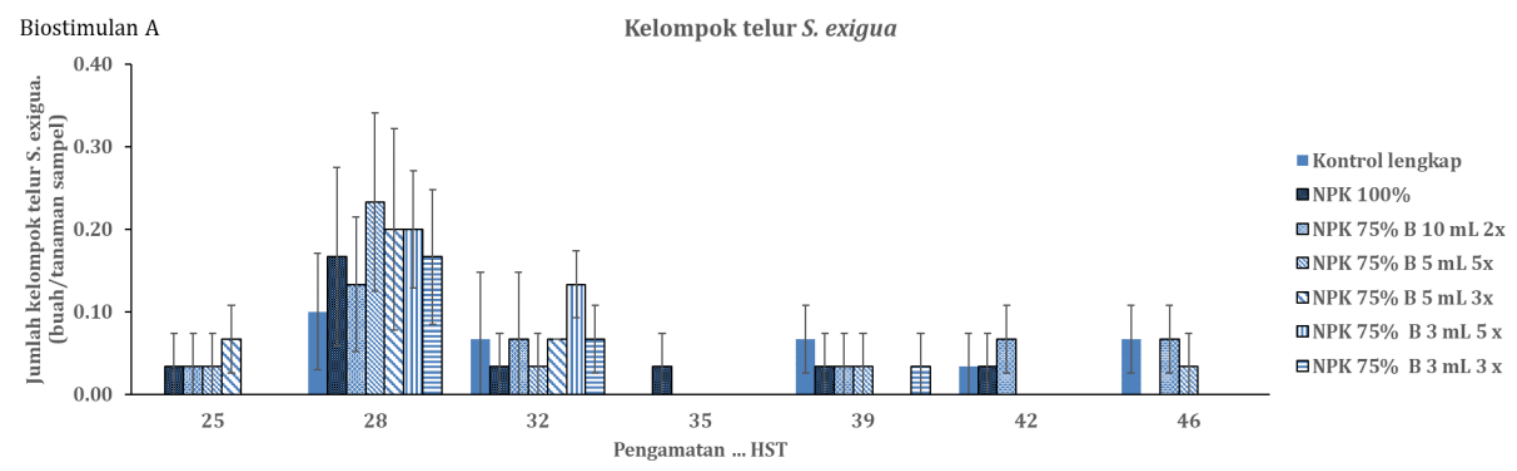

Gambar 3. Rerata jumlah kelompok telur S. exigua pada tanaman bawang merah yang diaplikasi dengan Biostimulan A 


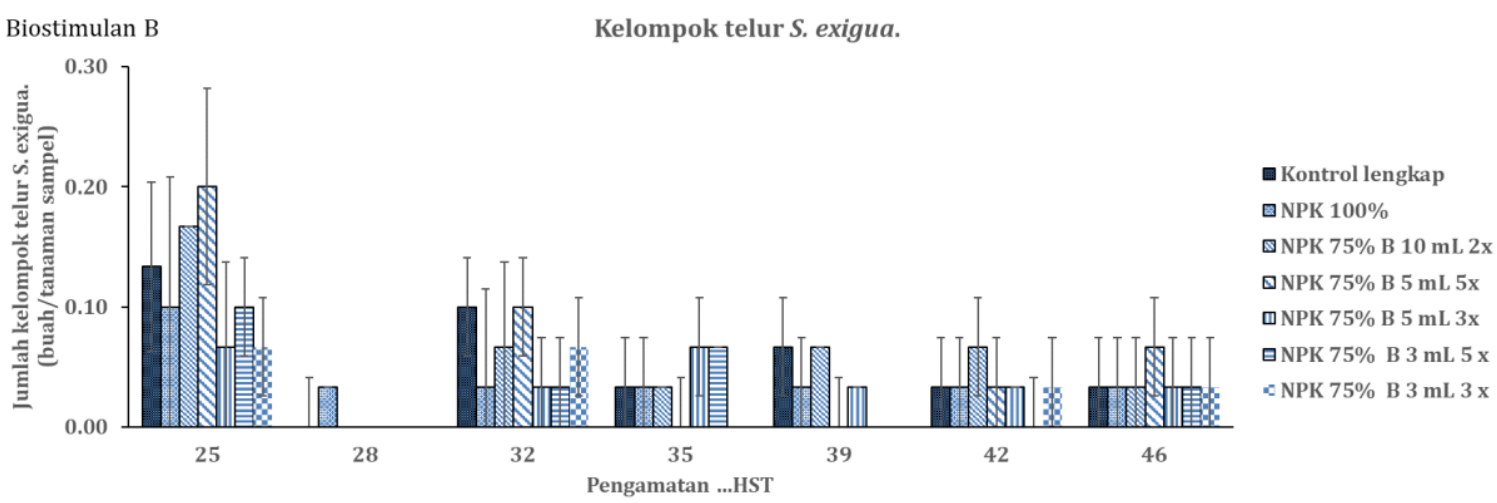

Gambar 4. Rerata jumlah kelompok telur $S$. exigua pada tanaman bawang merah yang diaplikasi dengan Biostimulan B

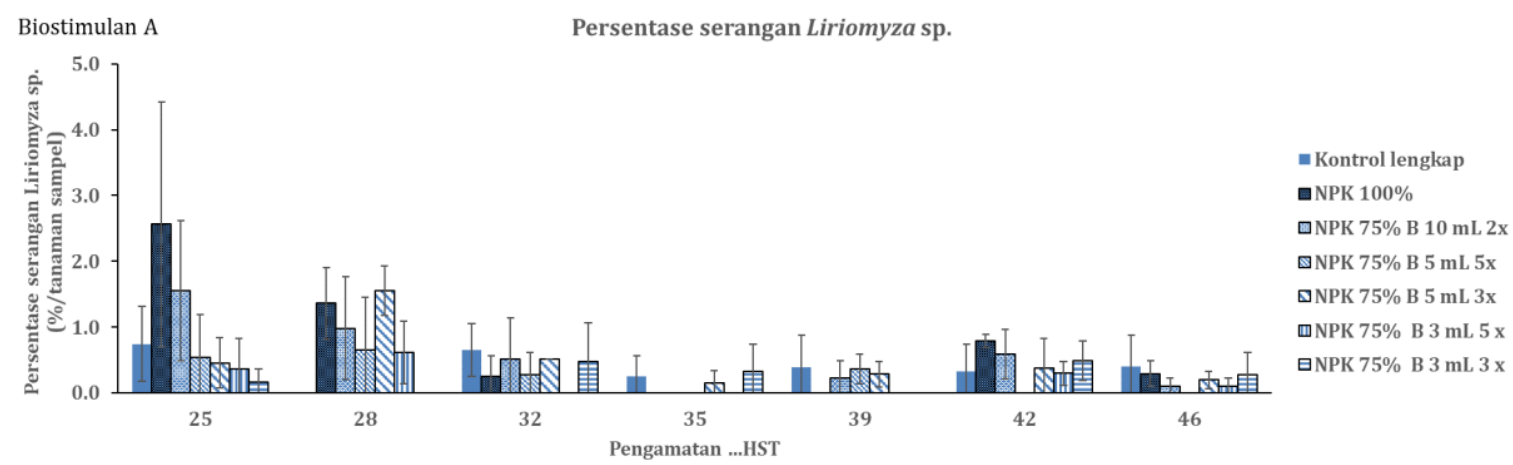

Gambar 5. Peresentase serangan Liriomyza sp. pada tanaman bawang merah yang diaplikasi dengan Biostimulan A

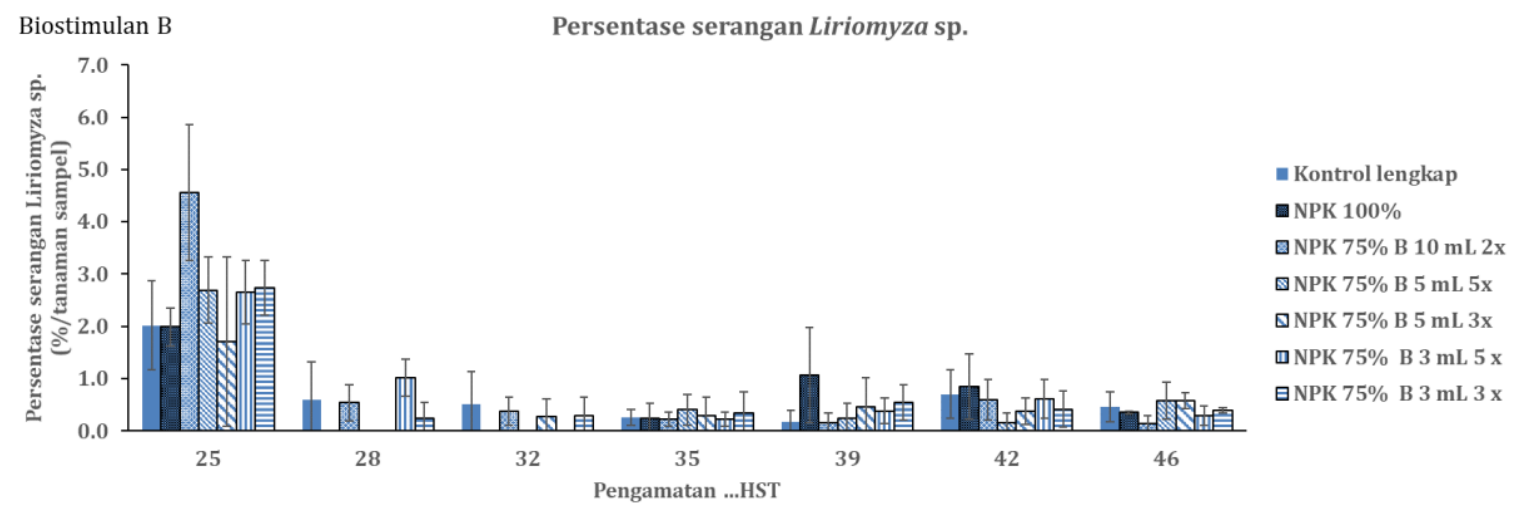

Gambar 6. Peresentase serangan Liriomyza sp. pada tanaman bawang merah yang diaplikasi dengan Biostimulan B

Hasil pengamatan menunjukkan bahwa serangan hama utama bawang merah (S. exigua dan Liriomyza sp.) pada berbagai konsentrasi dan frekuensi penyemprotan biostimulan A tidak menunjukkan perbedaan yang nyata, ditandai dengan nilai standard error yang saling bertautan. Demikian juga serangan hama pada tanaman bawang merah yang mendapatkan perlakuan dengan biostimulan B. Hal tersebut menunjukkan bahwa aplikasi biostimulan A dan B yang digunakan dalam pengujian ini belum 
mampu meningkatkan pertahanan tanaman melawan serangan hama.

Penelitian sebelumnya menunjukkan bahwa rumput laut dapat berfungsi sebagai substitusi pupuk karena kandungan mineral zat pengatur tumbuh seperti auksin, sitokinin, dan giberelin yang dimilikinya. Selain dapat meningkatkan pertumbuhan tanaman, ekstrak rumput laut juga meningkatkan efisiensi penggunaan nutrisi, membantu pembentukan buah, meningkatkan ketahanan tanaman terhadap cekaman biotik (hama dan penyakit) dan cekaman abiotik (kekeringan, salinitas maupun suhu yang ekstrim) (Mukherjee \& Patel, 2020). Penelitian tentang pengaruh biostimulan pada ketahanan terhadap penyakit tanaman lebih banyak dilakukan dibanding terhadap hama tanaman. Aplikasi formulasi ekstrak rumput laut (Stimplex ${ }^{\mathrm{TM}}$ ) terbukti dapat menurunkan serangan Alternaria cucumerinum dan Fusarium oxysporum pada tanaman mentimun. Kombinasi teknik aplikasi Stimplex ${ }^{\mathrm{TM}}$ dengan cara pengocoran dan penyemprotan akar memberikan hasil yang lebih baik dibandingkan teknik pengocoran dan pengocoran yang dilakukan secara terpisah (Jayaraman, 2011). Ekstrak rumput laut tersebut diduga dapat meningkatkan ketahanan terhadap penyakit melalui pengaruhnya dalam menginduksi mekanisme gen atau enzim pertahanan tanaman. Seperti misalnya kandungan $\lambda$-carrageenan dalam rumput laut membantu menghasilkan serangkaian gen yang terkait pertahanan terhadap serangan penyakit pada tanaman tembakau (Mercier et al., 2001). Sementara itu sulfated polysaccharides yang diisolasi dari isolated Ulva fasciata diduga dapat menginduksi ketahanan buncis terhadap antraknos yang disebabkan oleh Colletotrichum lindemuthianum (Paulert et al. 2009).

Dalam penelitian ini, biostimulan diaplikasikan pada tanaman dengan cara dikocorkan pada bagian perakaran tanaman bawang merah sesuai dengan tujuannya untuk meningkatkan pertumbuhan tanaman. Oleh karena itu, serangan hama bawang merah pada penelitian ini tidak terpengaruh oleh adanya aplikasi biostimulan diduga karena metode aplikasinya yang memang tidak dikhususkan untuk pengendalian serangga hama. Penelitian sebelumnya menunjukkan bahwa ekstrak rumput laut berpotensi sebagai larvisida dengan metode pemaparan ekstrak rumput laut pada larva. Seperti misalnya ekstrak Sargassum sp. yang dapat menimbulkan kerusakan morfologi pada larva Aedes aegypti Instar III (Sari et al. 2020). Selain itu ekstrak rumput laut Bryopsis pennata juga dapat menghambat pertumbuhan dan menimbulkan kerusakan morfologi larva Aedes aegypti (Yu et a.l, 2015).

Oleh karena itu, untuk mendapatkan informasi lebih lanjut tentang potensi ekstrak rumput laut untuk pengendalian hama diperlukan penelitian lebih lanjut tentang metode aplikasi yang tepat. Hal ini perlu dilakukan mengingat besarnya potensi yang dimiliki sektor kelautan Indonesia untuk mendukung peningkatan produksi tanaman melalui sumber daya rumput laut yang tinggi (Basmal, 2009).

\section{KESIMPULAN}

Tingkat serangan $S$. exigua dan Liriomyza sp. pada tanaman bawang merah tidak dipengaruhi oleh biostimulan yang diaplikasikan dalam penelitian ini.

\section{SUMBER DANA PENELITIAN}

Penelitian ini dilaksanakan dengan dana DIPA BB Biogen Tahun Anggaran 2021.

\section{DAFTAR PUSTAKA}

Abbas, S.M. 2013. The Influence of Biostimulant on The Growth and on The Biochemical Composition of Vicia faba $c v$. Giza 3 beans. Romanian 
Biotecnological Letters, 18(2); 8061-8068

Azri. 2017. Pengaruh Biostimulan Terhadap Pertumbuhan dan Produksi Bawang Merah di Lahan Gambut. Balai Pengkajian Teknologi Pertanian Kalimantan Barat. J. Pertanian Agros. Vol. 19(2).

Badan Pusat Statistik dan Direktorat Jenderal Holtikultura. 2021. Produksi Bawang Merah Menurut Provinsi. https://www.pertanian.go.id.

Basmal, Jamal. 2009. Prospek pemanfaatan rumput laut sebagai bahan pupuk organik Squalen Vol. 4 No. 1.

Calvo, P. L. Nelson, \& J.W. Kloepper. 2014. Agricultural uses of plant biostimulants. Plant Soil 383: 3 41. DOI: https://doi.org/10.1007/ s11104-014-2131-8

Craigie, C.R, E.A. Navajas, R.W. Purchas, C.A. Maltin, L. Bünger, S.O. Hoskin,

D.W. Ross. S.T. Morris, R. Roehe. 2012. A review of the development and use of video image analysis (VIA) for beefcarcass evaluation as an alternative to the current EUROP system and othersubjective systems.

Review. JurnalMeat Science. 92:307-318

Du Jardin, P. 2012. Plant Biostimulants: Definition, concept, main categories and regulation. Scientia Horticulturae. j.scienta.2015.09.021

Gusmaini, Aziz S. A, Munif A, Sopandie D \& Bermawie N. 2013. Potensi Bakteri Endofit Dalam Upaya Meningkatkan Pertumbuhan, Produksi, dan Kandungan Andrografolid Pada Tanaman Sambiloto. Balai Penelitian Tanaman Rempah dan Obat Bogor
Jalan Tentara Pelajar No. 3, Bogor, dan Fakultas Pertanian, Institut Pertanian Bogor. Jurnal Littri. 19(4): 167-177.

Handayani D. 2016. Keberadaan Cendawan Dark Septate Endophyte (Dse) Pada Sistem Perakaran Benih Shorea Selanica. Jurusan Biologi FMIPA Universitas Negeri Padang. Eksakta. Vol. 1(17):39

Jayaraman, Jayaraj, Norrie, Jeff \& Punja, Zamir K. 2011. Commercial extract from the brown seaweed Ascophyllum nodosum reduces fungal diseases in greenhouse cucumber. Journal of Applied Phycology 23, 353-361. DOI 10.1007/s10811-010-9547-1

Khan, W., Usha, P.R., Subramanian, S., Jithesh, M.N., Rayorath, P., D. Mark Hodges, P.D., Critchley, A.T., Craigie, J.S., Jeff Norrie, J. \& Prithiviraj, B. 2009. Seaweed Extracts as Biostimulants of Plant Growth and Development. J Plant Growth Regul 28:386-399. DOI 10.1007/s00344- 009-9103-x

Kumar, G. \& Sahoo, D. 2011. Effect pf seaweed liquid extract on growth and yield of Triticum aestivum var. Pusa Gold. J. Appl. Phycol. 23:251-255.

Marliah Ainun, Nurhayati, \& Tarmizi. 2012. Pengaruh Jenis Mulsa Dan Konsentrasi Pupuk Organik Cair Super Bionik Terhadap Pertumbuhan Dan Hasil Bawang Merah (Allium ascalonicum L.) Prodi Agroteknologi Fakultas Pertanian.

Matysiak, K., Kaczmarek, S. \& Krawczyk, R. 2011. Influence of Seaweed Extracts and Mixture of Humic and Fulvic Acids on Germination and Growth of Zea mays L. Acta Sci. Pol., Agricultura 10(1):33-45.

Mercier, L., Lafitte, C., Borderies, G., Briand, X., Esquerré-Tugayé, M., 
\& Fournier, J. 2001. The algal polysaccharide carrageenans can act as an elicitor of plant defense. New Phytologist. 149(1): 43-51. https://doi.org/10.1046/j.14698137.2001.00011.x

Mukherjee, A. \& Patel, J. S. 2020. Seaweed extract: biostimulator of plant defense and plant productivity. International Journal of Environmental Science and Technology 17, 553-558

Paulert, R., Talamini, V., Cassolato, J.E.F. et al. 2009. Effects of sulfated polysaccharide and alcoholic extracts from green seaweed Ulva fasciata on anthracnose severity and growth of common bean (Phaseolus vulgaris L.). J Plant Dis Prot 116, 263-270 (2009). https://doi.org/10.1007/BF033563 21

Sari, AP., Yudiati, E., \& Sunaryo. 2020.

Toksisitas Partisi N-Heksan dan Etil Asetat pada Ekstrak Sargassum sp. terhadap Larva Aedes aegypti Instar III. Journal of Marine Research Vol 9(2): 143-150 DOI : 10.14710/jmr.v9i2.26528

Vijayanandth Chermapandi, Parthiban.,

Saranya, C., Hemalatha, Annadurai., Kavith.B., Anantharaman, P. 2013. Effect Of Seaweed Liquid Fertilizer Of Spatoglossum Asperum On The Growth And Pigment Content Of Vigna Radiata. Vol: 4 (2):141-153 International Journal of Recent Scientific Research.

Yu K.X., Ching L.W., Rohani A., Ibrahim J. (2015). Larvicidal Activity, Inhibition Effect on Development, Histopathological Alteration and Morphological Aberration Induced by Seaweed Extract in Aedes aegypti (Diptera: Culicidae). Asian Pacific Journal of Tropical
Medicine 8(12): 1006-1012. doi: 10.1016/j.apjtm.2015.11.011 